\title{
WYKORZYSTANIE BARW W KSZTALTOWANIU WIZERUNKU INSTYTUCJI KULTURY
}

Alicja BaczyńSKa-HrYHOROWICZ

Instytut Nauk o Kulturze UMCS

Institute of Culture Studies

Maria Curie-Sklodowska University in Lublin

alicja.baczynska@poczta.umcs.lublin.pl

ORCID: 0000-0001-7000-7644

\section{WPROWADZENIE}

Jednym z najistotniejszych celów zarządzania jest uzyskanie i utrzymanie korzystnego wizerunku wśród odbiorców. Przekłada się on na sympatię klientów, która jest nieoceniona w procesie realizowania strategii rozwoju. Na wizerunek składa się wiele komponentów - jednym z nich jest aspekt wizualny, którego podstawowym elementem są barwy ${ }^{1}$. Wykorzystanie kolorów w budowaniu wizerunku organizacji jest podstawowym zagadnieniem niniejszego artykułu.

Temat wskazuje na przyjęte założenie badawcze: kolory mogą mieć wpływ na wizerunek organizacji. Tezę tę stawiam, opierając się na przekonaniu, że kolory oddziałują na człowieka zawsze, niezależnie od tego, czy jest tego świadomy i bez względu na kontekst, w jakim występują. Oddziaływać mogą więc również w przestrzeni organizacji i poprzez wysyłane przez nią komunikaty wizualne. Wpływ barw na postrzeganie instytucji ma swoje źródło w mechanizmie percepcyjnym - wrażenie, jakie pozostaje w umyśle człowieka po kontakcie z barwą, zostaje powiązane z sytuacją, w której go doświadczył². W ten sposób następuje ciąg skojarzeń kolor-instytucja.

1 Posługuję się wymiennie określeniami „kolor” i „barwa”, traktując je jako synonimy, tak jak ma to miejsce w języku potocznym. Podobnie traktować będę pojęcia „instytucja” i „organizacja”. Używając ich, mam na myśli podmiot zbiorowy, który jest w stanie świadomie kształtować własny wizerunek.

2 S. Popek, Barwy i psychika: percepcja, ekspresja, projekcja, Lublin 2012, s. 81-83. 
Wrażenia wywołane kolorem zostają przeniesione na odczucia względem organizacji, a w dalszej kolejności wpływają na jej wizerunek pozostający w umyśle odbiorcy. Zakładając prawdziwość opisanego wyżej związku, stawiam sobie za cel odpowiedź na pytanie, w jaki sposób można wykorzystywać barwy w kreowaniu wizerunku instytucji, szczególnie uwzględniając perspektywę instytucji kultury.

W tekście opisane zostaną pokrótce zagadnienia wizerunku i barwy, a następnie ich powiązania. Analiza tych zależności pozwoli wyodrębnić sposoby użycia koloru w budowaniu wizerunku, metody, jakimi można się w tym celu posłużyć, ograniczenia, jakie się z tym wiążą, oraz efekty, jakie mogą przynieść określone wybory kolorystyczne. Tezy przedstawione w części teoretycznej tekstu zostaną zweryfikowane poprzez badania etnograficzne. Badania prowadzone były w krakowskich instytucjach kultury; bazowały na obserwacji uczestniczącej oraz wywiadach swobodnych z pracownikami ${ }^{3}$. Wyniki badań rzucą światło na to, jak wykorzystywanie koloru w kreowaniu wizerunku instytucji wygląda w praktyce.

\section{WIZERUNEK INSTYTUCJI}

Słownik Języka Polskiego PWN podaje, że wizerunek to „sposób, w jaki dana osoba lub rzecz jest postrzegana i przedstawiana"4. Ta zwięzła definicja dotycząca ogólnej istoty wizerunku oddaje też jego sedno w kontekście zarządzania. Wizerunek nie jest bowiem niczym innym jak subiektywnym wyobrażaniem na temat danej instytucji, podzielanym przez jednostki lub grupy. Ewa Musiałowska pisze, że wizerunek można rozumieć jako „obrazy danego przedmiotu, które znajdują się w naszych głowach"5. Jest on więc nie tyle rzeczywistością, co zmodyfikowanym odbiciem rzeczywistości, w którym zawiera się szereg spostrzeżeń i wyobrażeń. Wizerunek pojawia

3 Wywiady zostały przeprowadzone w okresie marzec-maj $2016 \mathrm{w}$ ramach przygotowywania pracy magisterskiej w Instytucie Kultury Uniwersytetu Jagiellońskiego w Krakowie.

${ }^{4}$ http://sjp.pwn.pl/slowniki/wizerunek.html [dostęp 14.04.2020].

5 E. Musiałowska, Budowanie wizerunku przez symbole, [w:] Kształtowanie wizerunku, red. B. Ociepka, Wrocław 2005, s. 55-56. 
się w umyśle odbiorcy przy każdej styczności z firmą, jej produktem lub reklamą i warunkuje zachowanie względem nich ${ }^{6}$.

Do czynników wpływających na wizerunek zaliczyć można: obiektywne cechy instytucji (profil działalności, lokalizacja, kraj pochodzenia), konstrukcję psychiczną jednostki (potrzeby, motywacje, przekonania), oddziaływanie tzw. osób trzecich (rodziny, przyjaciół czy autorytetów w danej dziedzinie) $)^{7}$. Przede wszystkim jednak wizerunek jest zależny od rodzaju komunikatów, jakie kreuje, a następnie wysyła odbiorcom organizacja.

Podstawowymi generatorami pozytywnego wizerunku są: widoczność (i związana z nią rozpoznawalność), wyróżnienie (posiadanie skonkretyzowanej marki, którą można łączyć z określonymi atrybutami, takimi jak nazwa, znak graficzny, slogan), autentyczność (czyli zgodność między zasadami deklarowanymi a praktycznie stosowanymi), przejrzystość (transparentny przepływ informacji) oraz spójność (harmonizacja wszystkich działań or-


widoczność, brak charakterystycznej marki, nieautentyczność, brak klarownych informacji i niespójność w podejmowanych działaniach.

Pozytywny wizerunek organizacji ma niezaprzeczalny wpływ na zainteresowanie odbiorców. Przychylnie nastawieni klienci chętniej korzystają z oferty instytucji, są skłonni więcej zapłacić za jej produkty, interesują się możliwością pracy w niej, życzliwie wypowiadają się na jej temat w swoim środowisku. W związku z tym, dbanie o wizerunek ma dla instytucji znaczenie strategiczne i może być traktowane jako źródło przewagi konkurencyjnej oraz jeden z kluczowych czynników sukcesu' ${ }^{9}$. Pozytywny wizerunek

${ }^{6}$ K. Huber, Image, czyli jak być gwiazdą na rynku, tłum. J. Sukiennicki, Warszawa 1994, ss. 26-27, 35.

7 J. Szocki, Wizerunek firmy w mediach, Poznań-Wrocław 2008, s. 34.

8 T. Dąbrowski, Reputacja przedsiębiorstwa: tworzenie kapitału zaufania, Kraków 2010, s. 86-138.

9 Badania realizowane w 2003 r. pod kierunkiem Jolanty Zrałek dowiodły, że blisko $80 \%$ konsumentów dokonując zakupu, bierze pod uwagę „powszechną opinię o producencie danego towaru”; $88 \%$ respondentów zgodziło się ze zdaniem: „pozytywna opinia o firmie budzi zaufanie do produktu”, a 54\% ze sformułowaniem: „zakup produktu firmy o złej reputacji można uznać za zachowanie nieracjonalne" (zob. 
zapewnia zarówno efektywne działanie, jak i harmonijny rozwój ${ }^{10}$. Dlatego: „nie można funkcjonować w przestrzeni publicznej, ignorując aspekty wizerunkowe i konsekwencje ich istnienia"11.

Wymóg kształtowania własnego wizerunku nie omija instytucji kultury. Liczba podmiotów tego sektora wciąż się powiększa - branża kultury jest jedną z najdynamiczniej rozwijających się gałęzi gospodarki ${ }^{12}$. W związku z wielością organizacji zajmujących się szeroko pojętą działalnością kulturalną (domy kultury, muzea, teatry, kina, filharmonie, biblioteki itp.) pojawia się konkurencja między poszczególnymi placówkami. Jest ona tym większa, że współczesne społeczeństwo ma do dyspozycji szereg różnorodnych rozrywek, często tańszych, mniej wymagających intelektualnie czy szerzej dostępnych niż produkty i usługi, które oferują instytucje kultury. Dlatego przedsiębiorstwa działające w tym sektorze muszą nie tylko konkurować ze sobą nawzajem, ale też zabiegać o zainteresowanie odbiorców. Ponadto większość z nich (szczególnie instytucje publiczne) boryka się z problemami finansowymi, więc zwiększenie sprzedaży własnych usług jest często niezbędne dla zbilansowania budżetu. W obliczu takiej sytuacji przyjęcie przez instytucje kultury zasad marketingu, public relations i kształtowania wizerunku wydaje się koniecznością.

Przy planowaniu wyżej wymienionych działań konieczne jest przeanalizowanie specyficznych uwarunkowań właściwych tylko branży kulturalnej, jak np. grupy interesariuszy ${ }^{13}$. Prócz uniwersalnych dla wszystkich typów instytucji (media, lokalne władze, instytucje finansowe) są i szczególne: kuratorzy, mecenasi, artyści. Unikalny będzie również profil klienta instytucji kultury. Do korzystania z oferty skłania go najczęściej motywacja

J. Zrałek, Znaczenie wizerunku przedsiębiorstwa w wyborach konsumentów (w świetle racjonalności), Katowice 2005).

10 A. Żbikowska, Public relations, Warszawa 2005, s. 43-44.

${ }^{11}$ I. Borkowski, K. Stasiuk-Krajewska, Wizerunek, opis świata, konstrukcja komunikacji, [w]: Kształtowanie wizerunku jako narządzie public relations, red. I. Borkowski, K. Stasiuk-Krajewska, Wrocław 2011, s. 12.

12 A. Niemczyk, Marketing w sferze kultury, Kraków 2007, s. 8.

13 Pod pojęciem interesariuszy (ang. stakeholder) rozumie się grupy lub osoby zainteresowane działalnością organizacji, które pozostają pod jej wpływem i mogą oddziaływać na realizację jej celów. 
pozytywna, to znaczy wynikająca np. z poszukiwania intelektualnej stymulacji lub estetycznej przyjemności, a nie z chęci usunięcia problemu lub zlikwidowania niedogodności. Dodatkowo jest on silnie zaangażowany emocjonalnie $\mathrm{w}$ proces nabycia produktu, a ocena i interpretacja tegoż produktu ma wymiar silnie subiektywny ${ }^{14}$. Również sam „produkt kultury” jest specyficzny. Ma on bowiem najczęściej charakter usługi, która jest niematerialna, nietrwała i niepowtarzalna ${ }^{15}$.

Generalne założenia kształtowania wizerunku pozostają jednak niezmienne, bez względu na to, jakiej branży dotyczą. Zarządzający wizerunkiem instytucji kultury mogą zatem swobodnie korzystać z rozwiązań wypracowanych przez praktyków zarządzania w biznesie. Nie mogą jednak zapominać o osobliwości swojej branży. Każde wdrożone działanie powinno zostać dostosowane do specyfiki sektora kultury.

\section{BARWY A KSZTAETOWANIE WIZERUNKU}

Wśród licznych czynników składających się na wizerunek instytucji, najbardziej interesują mnie te mające wymiar estetyczny. Istotność estetyki we współczesnym świecie nieustannie rośnie, a specjaliści zarządzania przyznają, że ma ona kluczowe znaczenie w osiągnięciu rynkowego sukcesu: „W świecie, w którym większość podstawowych potrzeb konsumentów jest już zaspokojona, wyższe wartości najłatwiej przekazać za pomocą spełniania sprawdzalnych empirycznie potrzeb estetycznych"16.

Proces zarządzania estetyką koncentruje się wokół tożsamości wizualnej organizacji (corporate design), która kształtowana jest przez system identyfikacji wizualnej, czyli zbiór opracowanych graficznie elementów, za pomocą których odbiorcy identyfikują organizację i obszar jej działań ${ }^{17}$. Na system identyfikacji wizualnej składają się elementy z dwóch grup: stałej

14 J. Woźniczka, Uniwersalność koncepcji marketingowej a specyfika rynku kultury i sztuki, [w:] Kultura w gospodarce rynkowej. Problemy adaptacji marketingu, red. K. Mazurek-Łopacińska, Warszawa-Wrocław 1997, s. 130.

15 A. Niemczyk, op. cit., s. 42-43.

16 B. Schmitt, A. Simonson, Estetyka w marketingu, tłum. M. Bernacki, Kraków 1999, s. 24-25.

17 M. Snarska, Corporade design - wizualizacja tożsamości, [w:] Kształtowanie wizerunku, red. B. Ociepka, Wrocław 2005 s. 165. 
i wtórnej. Do pierwszej należą: logo, kolorystyka i typografia - są one prymarne w kształtowaniu wizualnej tożsamości i uniwersalne dla każdego typu organizacji. Na ich podstawie powstają elementy wtórne: druki (wizytówki, ulotki, katalogi), strony internetowe, forma opakowania produktów, oznakowanie budynków, aranżacja wnętrz, stroje pracowników ${ }^{18}$.

Nadrzędnym zadaniem corporate design jest stworzenie „użytecznego oraz czytelnego dla odbiorców wizualnego systemu uprzednio zwerbalizowanej tożsamości"19. Oznacza to, że o komunikatach wizualnych nie można myśleć w oderwaniu od innych elementów strategii budowania wizerunku i zarządzania organizacją. Identyfikacja wizualna powinna zachować spójność z całym systemem komunikacji. Jednocześnie system ten powinien odznaczać się oryginalnością, wysoką zauważalnością oraz być łatwy w percepcji i zapamiętywaniu ${ }^{20}$. „Obraz firmy winien przekazywać i utrwalać informacje podkreślające główną cechę produktu. Ponadto musi swój przekaz uczynić na tyle oryginalnym, aby nie pokrywał się z przekazem konkurencji, ale jednocześnie na tyle wyrazistym, aby wpływać zarówno na sferę rozumowania logicznego, jak i emocje danej grupy klientów” - twierdzi Zbigniew Bentyn ${ }^{21}$.

Uniwersalnym elementem spajającym i przenikającym wszystkie składniki wizualnej tożsamości jest kolor, który oddziałuje na odbiorcę na wielu poziomach. „W zakresie emocjonalnym efekt koloru jest pozytywny: barwne bardziej się podoba, bardziej zaciekawia, wzbudza większe zainteresowanie, stwarza wrażenie nowoczesności, młodości i przygody, wytwarza uczucia, nastroje, iluzje"22 - dowodzi Eleonora Grimm. Małgorzata Snarska uważa, że kolor nadaje komunikowaniu nowy wymiar: „ożywia symbol, podnosi jego jakość, ułatwia odbiór, przyciąga uwagę i wywołuje reakcję"23. Anna Benicewicz-Miazga twierdzi, że człowiek odbierając komunikat marketingowy, w pierwszej kolejności zwraca uwagę na barwę, dopiero potem na

18 Ibidem, s. 167.

19 Ibidem.

20 A. Benicewicz-Miazga, Grafika w biznesie. Logotypy, wizytówki, papier firmowy. Projektowanie elementów tożsamości wizualnej, Gliwice 2005, s. 10.

${ }_{21}$ Z. Bentyn, Identyfikacja wizualna przedsiębiorstwa, Poznań 2011, s. 23.

22 E. Grimm, Kolor w środkach masowego przekazu, tłum. b.d., Kraków 1971, s. 71.

${ }^{23}$ M. Snarska, op. cit., s. 171. 
formę, nazwę i liczbę ${ }^{24}$. Kurt Huber wymienia zaś kolor jako najważniejszy aspekt oceny produktu przez klienta, obok ceny, formy i prestiżu ${ }^{25}$. O kluczowej roli koloru w procesie identyfikacji marki świadczy fakt, że barwa może być chroniona prawnie jak znak towarowy, jeśli ma „zdolność odróżniającą", czyli identyfikuje towary lub usługi z podmiotem, od którego pochodzą. W Polsce status znaku towarowego ma chociażby kolor fioletowy dla oznaczenia wyrobów czekoladowych marki Milka, czy pomarańczowy dla telefonii komórkowej Orange ${ }^{26}$.

„Posiadając wiedzę na temat znaczenia i właściwości kolorów, można wykorzystać pojedynczą barwę lub całą paletę w celu wyrażenia tych cech wizerunku, z którymi pragnie utożsamić się firma" - twierdzi Ewa StopaPielesz ${ }^{27}$. To właśnie podstawowe założenie wykorzystania barw w kształtowaniu wizerunku - wykorzystać ich cechy tak, by podkreślić znaczenia, jakie chce się nadać promowanej organizacji. Właściwości barw podzielić można na psychofizyczne i symboliczne.

Właściwości psychofizyczne wynikają z faktu, że kolory są niczym innym jak zjawiskiem fizycznym, czyli falą świetlną o określonej długości i częstotliwości drgań. W licznych eksperymentach udowodniono ich wpływ na ludzki organizm ${ }^{28}$. Barwy ciepłe (żółta, czerwona, pomarańczowa i pokrewne) mają działanie pobudzające, przyśpieszają oddech i tętno, wywołują ożywienie, dodają energii. Barwy zimne (zielona, niebieska, fioletowa) odwrotnie - hamują i uspokajają system nerwowy, sprzyjają więc skupieniu i koncentracji ${ }^{29}$. Ponieważ barwy odbieramy za pomocą narządu wzroku, ich percepcja często zależna jest od mechanizmów jego funkcjonowania. Najlepszym tego przykładem jest zdolność barw do pozornego zmieniania

24 A. Benicewicz-Miazga, op. cit., s. 7.

25 K. Huber, op. cit, s. 137.

26 D. Popiel, Ochrona prawna marki, [w:] Instrumenty kształtowania wizerunku marki, red. A. Grzegorczyk, Warszawa 2005, s. 59-61.

27 E. Stopa-Pielesz, Corporate design: czyli jak sprawić, by estetyka pracowała na sukces firmy, Kraków 2002, s. 49.

28 Zob. S. Popek, op. cit., s. 84-92.

29 G. Zaugner, Barwa i człowiek, tłum. J. Rogaczewski, Warszawa 1965, s. 127. 
kształtu i objętości pomieszczenia - jasne kolory optycznie rozszerzają i powiększają, a ciemne zawężają i zmniejszają ${ }^{30}$.

Nie mniej istotne są symboliczne właściwości koloru. We współczesnej kulturze każdej barwie podstawowej przypisane są określone skojarzenia i wartości. Fakt ten powoduje, że w poszczególnych kontekstach używane są niemal wyłącznie konkretne odcienie. Czerwień pojawia się tam, gdzie poruszany jest temat miłości, zieleń - gdy mowa o przyrodzie i naturze. Symbolika kolorów sprawia, że za ich pomocą można komunikować różnorodne informacje. Czarny ubiór na pogrzebie w wielu kulturach wyraża smutek, a biel, w którą odziane są w tradycji katolickiej idące do Pierwszej Komunii Świętej dziewczęta - ich czystość i niewinnośćc ${ }^{31}$. Symbolika barw często podtrzymywana i uwydatniana jest poprzez język, co widać w licznych związkach frazeologicznych („mieć zielono w głowie”, „patrzeć przez różowe okulary”, „być czarną owcą w rodzinie” itp. ${ }^{32}$.

Kolory mogą być jednak pozbawione zarówno psychofizycznego oddziaływania, jak i symbolicznej podbudowy, służąc jako znaki informacyjne o arbitralnie przypisanych znaczeniach (np. sygnalizacja świetlna, znaki drogowe, mapy). Mogą też być używane wyłącznie jako forma artystycznego przekazu, zależna od indywidualnych preferencji estetycznych.

Instytucje chcące wykorzystać kolor w kształtowaniu własnego wizerunku muszą brać pod uwagę wszystkie wspomniane powyżej właściwości barw. Kolory, będąc składową nie tylko świata zmysłów, ale też myśli i uczuć, są bardzo mocno zakorzenione w ludzkiej świadomości. Ich właściwe dobranie jest zadaniem niełatwym, ale z pewnością wartym wysiłku, gdyż tak jak silne jest oddziaływanie kolorów w codziennym życiu, tak silne będzie jako element wspomagający pożądany obraz instytucji w umysłach odbiorców. Choć każda organizacja indywidualnie podejmuje decyzje o kolorach

${ }^{30}$ G. Watermann, Kolor $w$ mieszkaniu: barwy, kształty, oświetlenie, materiały, tłum. A. Konopacka, Warszawa 1994, s. 104.

${ }_{31}$ Szerzej o symbolice barw w kulturze zob.: R. Gross, Dlaczego czerwień jest barwa miłości, tłum. A. Porębska, Warszawa 1990; G. Evans, Historia kolorów. Tajemniczy świat barw, tłum. W. Jeżewski, Warszawa 2019.

32 Szerzej na temat znaczenia barw we współczesnym języku polskim zob. R. Tokarski, Semantyka barw we współczesnej polszczyźnie, Lublin 2004. 
zbieżnych z jej tożsamością, praktycy zarządzania wskazują ogólne zasady ich stosowania.

Kolory ciepłe i jasne pobudzają, mają przyjazny charakter i mocno rzucają się w oczy, dlatego powinny być stosowane przez organizacje chcące pokazać się jako otwarte i dynamiczne, np. związane z rynkiem spożywczym lub odzieżowym. Barwy ciepłe, ale w ciemnym odcieniu, kojarzą się z klasyką i elegancją. Najlepiej nadają się zatem dla organizacji, które chcą wykreować wizerunek stylowych i tradycyjnych, np. instytucji finansowych, architektonicznych, prawniczych. Barwy zimne i jasne kojarzą się z nowoczesnością i świeżością, stąd często stosuje się je w produktach adresowanych do ludzi młodych i aktywnych, z branży sportowej, rozrywkowej i kosmetycznej. Ciemne i zimne kolory dają poczucie spokoju, powagi i stabilizacji. Nie wyróżniają się, dzięki czemu dobrze uwydatniają treść. Praktycy corporate design sugerują, by używać ich w przypadku instytucji rządowych, medycznych i naukowych ${ }^{33}$. Bez względu na to, jaki odcień zostanie użyty, jeśli będzie on intensywny i jaskrawy, wywoła wrażenie dominacji, gwałtowności, niekiedy wręcz agresji. Delikatne i stonowane odcienie dadzą natomiast efekt spokoju i równowagi, choć w skrajnych przypadkach także nudy i monotonni ${ }^{34}$. Niekiedy użycie określonego koloru wymusza bezpośrednio branża, w której działa organizacja. Przedsiębiorstwa związane z ekologią czy rolnictwem najpewniej wybiorą kolor zielony kojarzący się z naturą, zaś firmy świadczące usługi pogrzebowe muszą legitymować się barwami ciemnymi i stonowanymi.

Bodaj najważniejszą składową systemu identyfikacji wizualnej jest logotyp, który umieszcza się na większości wytworów instytucji. Dobrze opracowany wskazuje na swojego właściciela, nawet kiedy występuje w oderwaniu od innych identyfikatorów. Zazwyczaj nawiązuje do archetypicznych ikon i znaków, dzięki czemu sugestywnie trafia do ludzkiej świadomości. Wybierając kolory, które znajdą się w logotypie, instytucja uwzględnić powinna przede wszystkim ich symbolikę (nie zawsze jednakową w zależności od kręgu kulturowego), ale również zjawiska i złudzenia optyczne (np.

33 A. Benicewicz-Miazga, op. cit., s. 91-94.

34 K. Wojcik, Public relations. Wiarygodny dialog z otoczeniem, Warszawa 2009, s. 80 . 
subiektywną zmianę dostrzeganych odcieni zależną od barw sąsiadujących albo odległości patrzenia).

Barwy pojawiają się także w przestrzeni organizacji - to również element identyfikacji wizualnej, ale rządzący się specyficznymi regułami. Duże płaszczyzny barwne (ściany, meble) oddziałują wizualnie znaczenie bardziej intensywnie niż małe (ulotki, gadżety) ${ }^{35}$, więc intensywna czerwień, która sprawdzi się w logotypie, może nie znaleźć zastosowania w wystroju wnętrza. Dodatkowo kolor w przestrzeni warunkowany jest takimi aspektami, jak: światło, cień, faktury, wzory i powierzchnie materiałów ${ }^{36}$. Większe znaczenie ma też estetyka - wnętrza muszą wyglądać harmonijne, by przebywające w nich osoby czuły się komfortowo ${ }^{37}$. Choć możliwość kolorystycznej kreacji przestrzeni często jest ograniczona, barwy w budynku powinny być spójne z ogólnym kodem kolorystycznym organizacji.

Jerzy Altkorn twierdzi, że system identyfikacji wizualnej jest szczególnie istotny w przypadku organizacji oferujących usługi niematerialne. W przeciwieństwie do przedsiębiorstw sprzedających produkty, usług nie można przed kupnem obejrzeć ani dotknąć. Brak ten firmy usługowe powinny wypełnić właśnie za pomocą wyrazistych i charakterystycznych komunikatów wizualnych ${ }^{38}$. W takiej właśnie sytuacji są instytucje kultury, które oferują odbiorcom usługi niematerialne. Istotną metodą komunikacji z otoczeniem powinna być dla nich zatem spójna i niebanalna tożsamość wizualna.

Organizacje kultury mają praktycznie nieograniczone możliwości wyboru swoich przewodnich barw. Branża, w której działają, nie posiada bowiem tradycyjnie przyporządkowanych symboli. W zależności od profilu działalności i grupy docelowej mogą decydować się na niemal dowolny typ barwnej palety. Kolory ciepłe, czyste i nasycone mogą być użyte w instytucjach, które skupiają się na działalności dla dzieci i młodzieży, np. w domach kultury. Instytucje, które chcą stworzyć wrażenie eleganckich i elitarnych (teatry, filharmonie), mogą postawić na ciemne tonacje z dodatkiem złota lub srebra. Kolory pastelowe powinny być idealne dla miejsc, które pragną

35 E. Stopa-Pielesz, op. cit., s. 98.

36 D. Hornung, Kolor. Kurs dla artystów i projektantów, tłum. M. Brand, Kraków 2009, s. 38 .

37 Ibidem, s. 97.

38 J. Altkorn, Wizualizacja firmy, Kraków 1999, s. 12. 
zaistnieć w świadomości odbiorców jako przyjazne i atrakcyjne dla całej rodziny, np. w muzeach. Ciekawym przykładem jest Wojewódzka Biblioteka Publiczna w Krakowie, która używa jako kolorów przewodnich granatowego i pomarańczowego (pojawiają się w logotypie i w projekcie strony internetowej $^{39}$ ). Granat to kolor spokojny i poważny, pomarańcz - żywy i radosny. Kontrast występuje tu zarówno na poziomie symbolicznym, jak i optycznym (tzw. kolory dopełniające się), jednocześnie jednak wydaje się, że dobrze odzwierciedla tożsamość, jaką chce kreować instytucja - klasyczną formę działania i nowoczesny sposób jej realizacji.

Dla instytucji kultury barwy mogą być przydatne również przy podkreślaniu różnorodności oferty, np. intensywne odcienie żółci oznaczające warsztaty dla dzieci, a stonowane odcienie żółci podobną ofertę kierowaną do seniorów. Przykładem wykorzystywania barw do podkreślenia złożonej działalności organizacji są największe krakowskie muzea: Muzeum Narodowe i Muzeum Krakowa (dawniej: Historyczne). Instytucje te składają się z kilkunastu oddziałów, z których każdy „oznaczony” jest odrębną barwą, co widoczne jest na stronie internetowej ${ }^{40}$ i na ulotkach reklamowych. Zabieg ten pomaga wyodrębnić w świadomości odbiorcy poszczególne oddziały i nadać im indywidualny charakter.

\section{WYKORZYSTANIE BARW - BADANIA INSTYTUCJI KULTURY}

Specyfika działalności instytucji kultury z pewnością stawia przed nimi szczególne wyzwania. W przypadku identyfikacji wizualnej sektor kultury zdaje się jednak mieć przewagę nad pozostałymi branżami. Nie ograniczają go utarte kolorystyczne skojarzenia, może swobodnie dobierać barwy przewodnie i uwzględniać ich wszystkie właściwości. Czy wykorzystuje ten fakt? W tej części artykułu przedstawię przykłady trzech instytucji, które odpowiadają na to pytanie twierdząco. Wstępna analiza pozwala stwierdzić, że mają one zdefiniowane kolory przewodnie, z których korzystają konsekwentnie, świadomie i w sposób czytelny dla odbiorcy. Są to: Filharmonia Krakowska, Muzeum Sztuki Współczesnej MOCAK oraz Opera Krakowska.

39 Zob. https://www.rajska.info/ [dostęp 16.04.2020].

40 Zob. https://mnk.pl/oddzialy, https://www.muzeumkrakowa.pl/oddzialy [dostęp 16.04.2020]. 


\section{FILHARMONIA KRAKOWSKA IM. KAROLA SZYMANOWSKIEGO}

Filharmonia Krakowska ma stabilną i ugruntowaną pozycję na kulturalnej scenie Krakowa. W 2020 roku obchodziła swoje 75-lecie, na stałe zagościła już więc w świadomości odbiorców. Jest najważniejszą muzyczną instytucją w Małopolsce, dlatego nie musi obawiać się konkurencji i nie grozi jej brak zainteresowania ze strony interesariuszy. Przy tak komfortowej sytuacji wizerunkowej wykorzystywanie komunikatów wizualnych nie wydaje się być pilną koniecznością. Filharmonia ma jednak swoje barwy firmowe - biel i złoto. To harmonijne i wymowne połączenie. Złoto implikuje zamożność i dostatek, dając wrażenie prestiżu. Biel kojarzy się w tym kontekście z elegancją i wdziękiem. Znaczenia te bardzo dobrze korespondują z typem działalności instytucji, która uważana jest za wyrafinowaną rozrywkę dla wykształconej publiczności. Wspomniane barwy widoczne są w przestrzeniach budynku, w którym mieści się instytucja oraz w jej logotypie.

Budynek Filharmonii, monumentalny gmach na rogu ulic Straszewskiego i Zwierzynieckiej, zarówno na zewnątrz, jak i wewnątrz utrzymany jest w biało-kremowo-złotej tonacji (il. 1). Kolorystykę tę budynek otrzymał już w momencie powstania (w latach trzydziestych XX wieku) i nie zmieniła się ona praktycznie do dzisiaj. Z powodu zajmowania budynku, którego użytkowanie jest związane z ograniczeniami prawnymi (status zabytku) i własnościowymi (budynek należy do krakowskiej kurii), władze Filharmonii nie mogą wykorzystać pełni możliwości kreacji przestrzeni. Zarządzający wybrnęli jednak $\mathrm{z}$ tego problemu dostosowując się do narzuconej formy wizualnej. Zamiast starać się ją modyfikować, podkreślają jej charakter. Korytarze i sale koncertowe toną w złamanych bielach, jasnych brązach i obfitych złoceniach (il. 2).

Logotyp Filharmonii (il. 3) składa się ze złotego znaku oraz umieszczonego pod nim czarnego napisu. Znak przedstawia uproszczoną formę organów - pionowe linie o różnej długości i szerokości, skupione po trzy w pięciu grupach. Napis ułożony jest w trzech wersach i zawiera nazwę: Filharmonia im. Karola Szymanowskiego w Krakowie. Użycie w logo motywu organów uzasadnione jest nie tylko jednoznacznym skojarzeniem z muzyką. W Filharmonii Krakowskiej organy zajmują centralne miejsce sceny w głównej sali koncertowej, będąc dominantą wnętrza. Złoty kolor znaku w logotypie nawiązuje do faktycznego wyglądu instrumentu. Obecna wersja logotypu stworzona została na sezon artystyczny 2014/2015, kiedy to 


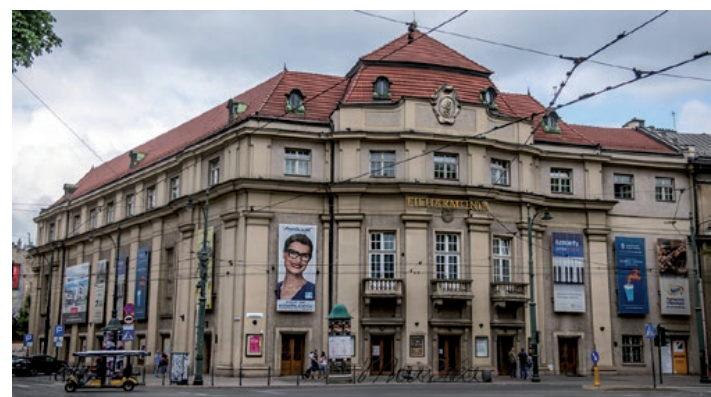

Il. 1



Il. 2

Filharmonia obchodziła swoje 70-lecie. Marcin Bańdo, kierownik działu promocji, w rozmowie ze mną przyznał, że zamierzeniem autora projektu było podkreślenie rangi i renomy krakowskiej Filharmonii: „Filharmonia jest czymś więcej niż kino, jest nawet może czymś więcej niż teatr... To jest tak zwana kultura z wyższej półki, wyższego rzędu, więc musi się kojarzyć prestiżowo. [...] Skojarzenie koloru [złotego - przyp. A.B-H.] jest też z czymś bogatym. Bogata oferta, bogaty świat muzyki i tak dalej" ${ }^{\prime 1}$.



\section{FILHARMONIA}

im. Karola Szymanowskiego W KRAKOWIE

Il. 3

${ }^{41}$ Fragment rozmowy z 4.04.2016 r. przeprowadzonej z kierownikiem Działu Promocji Marcinem Bańdo. 
Biało-złote barwy przewodnie nie sprawdzają się jednak we wszystkich sytuacjach. Na 70-lecie istnienia Filharmonia projektowała szereg gadżetów reklamowych, takich jak: torby, długopisy, kubki. Początkowy projekt ze złotymi piktogramami na czarnym tle nie zyskał jednak aprobaty osób odpowiedzialnych za zarządzanie wizerunkiem instytucji. Zdecydowano się na proste i uniwersalne zestawienie czerni i bieli, które było bardziej wyraziste. Przykład ten pokazuje elastyczność w korzystaniu z barwnych palet.

Marcin Bańdo przyznał, że aspekty wizualne, a wśród nich także kolorystyka, są ważną, choć nie kluczową częścią kształtowania wizerunku instytucji. Określił je jako „wartość dodaną” do oferty muzycznej. Sam wizerunek nazwał „najważniejszą rzeczą na świecie poza ofertą programową”, twierdząc: „Ludziom instytucja kultury musi kojarzyć się pozytywnie, ludzie muszą wiedzieć, że tutaj znajdą dobrą rozrywkę, miło spędzą czas, wyniosą stąd pozytywne wrażenia, o których będą dyskutować. I to wszystko powoduje wizerunek. Dzięki temu wizerunkowi ludzie tu przychodzą".

\section{MUZEUM SZTUKI WSPÓŁCZESNEJ W KRAKOWIE MOCAK}

Muzeum Sztuki Współczesnej MOCAK to instytucja działająca w przestrzeni Krakowa od 2011 roku. Od samego początku kreuje spójny, konsekwentny i wyrazisty wizerunek, w którym niebagatelne znaczenie odgrywa kolor. Barwy firmowe to czerń, biel oraz tony pośrednie, czyli szarości. Widać je w bryle budynku muzeum, logotypie, na stronie internetowej oraz w gadżetach promocyjnych. Inspiracją dla wyboru właśnie takich barw był budynek muzeum (il. 4). Biały to szkło, szary - beton, a czarny - płyty na elewacji. To architektura budynku zdefiniowała system identyfikacji wizualnej MOCAK- $\mathrm{u}^{42}$.

Architektoniczna forma muzeum jest dziełem włoskich architektów Claudia Nardiego i Leonarda Marii Proliego, których projekt został wybrany w roku 2007 na zasadach konkursu ${ }^{43}$. Całość nawiązuje do industrialnych początków miejsca (muzeum mieści się na terenie kompleksu dawnej Fabryki Oskara Schindlera) poprzez użycie metalu i betonu, które zrównoważone zostały przeszkleniami. Wnętrze jest minimalistyczne i surowe,

${ }^{42}$ Rozmowa z 25.03.2016 r. przeprowadzona z kierownikiem Działu Promocji Eweliną Czechowicz oraz grafikiem Muzeum MOCAK Rafałem Sosinem.

${ }^{43}$ Zob. https://www.mocak.pl/historia [dostęp 16.04.2020]. 


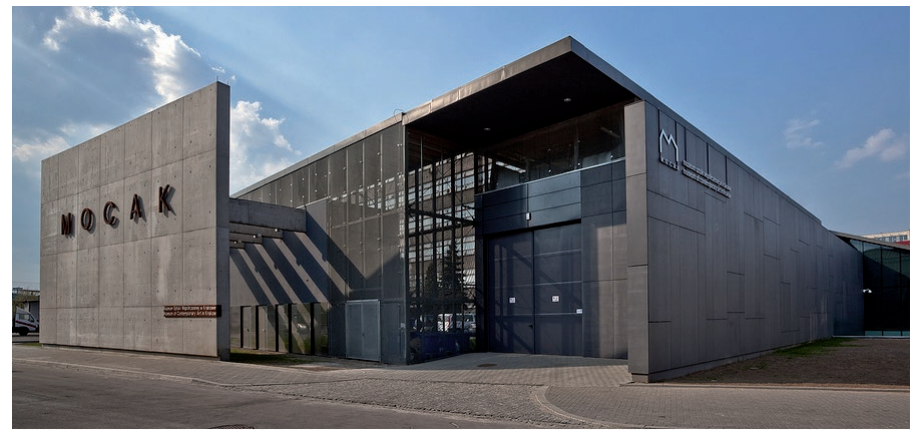

Il. 4

dominuje w nim biel i jasne szarości (il. 5). Także przestrzenie towarzyszące - kawiarnia, księgarnia, biblioteka - mają jednolity wyraz estetyczny. Cały kompleks wywołuje wrażenie oszczędnej prostoty - efekt ten wzmacniają achromatyczne tony barwne. Prócz nawiązania do wyglądu siedziby, czerń, biel i szarość mają też znaczenie praktyczne na ekspozycji: nie przyćmiewają dzieł sztuki. Są maksymalnie neutralne, dzięki czemu pozwalają zaistnieć kolorom użytym w pracach artystycznych.

Do kolorów przewodnich (oraz do architektury budynku) nawiązuje logotyp muzeum (il. 6), zaprojektowany przez Adama Szyszkę w ramach konkursu zorganizowanego w 2010 roku na Akademii Sztuk Pięknych ${ }^{44}$. Sygnetem jest gruba czarna linia ułożona w kształt charakterystycznych dla budynku, szedowych dachów. Po prawej stronie znaku znajduje się pisana czarnym prostym fontem nazwa muzeum. Całość umieszczona jest na białym tle, co tworzy maksymalny kontrast i podkreśla minimalizm projektu.

W bieli, czerni i szarościach utrzymana jest też strona internetowa ${ }^{45}$. Kolor pojawia się na niej w nagłówkach podstron zawartych w menu głównym. Każdy z obszarów działalności muzeum (kolekcja, edukacja, biblioteka itd.) ma swoją odrębną barwę. Te same kolory rozróżniające typ działalności pojawiają się też $\mathrm{w}$ materiałach promocyjnych, takich jak broszury i ulotki. Dobór kolorów nie ma tutaj kontekstu symbolicznego, ale stricte informacyjny. Kolor w roli identyfikującej pojawia się także w przypadku

44 Zob. https://www.mocak.pl/logo-mocak-u [dostęp 16.04.2020].

45 Zob. https://www.mocak.pl/ [dostęp 16.04.2020]. 


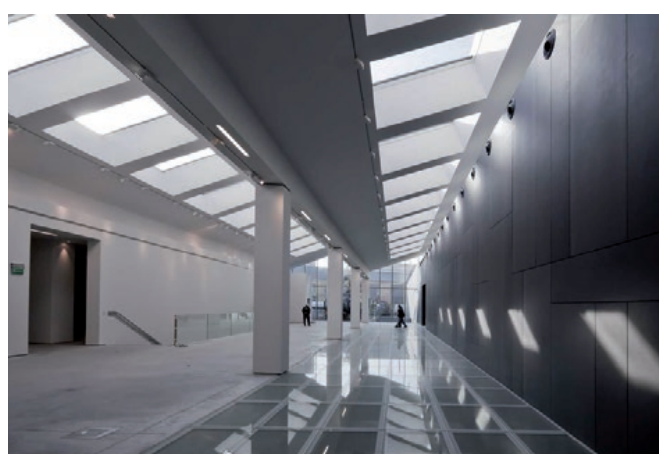

Il. 5

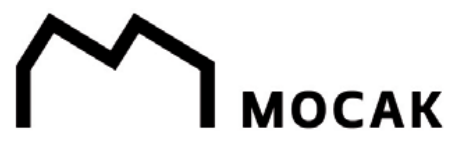

Il. 6

biletów, które mają różne wersje kolorystyczne w zależności od typu: bilet normalny - ciemna czerwień, ulgowy - róż, rodzinny - pomarańcz itp.

Kolor przewodni mają duże wystawy czasowe, które muzeum organizuje w ramach cyklu wystaw $W$ sztuce. Dominująca barwa wybierana jest pod kątem tematu wystawy, bez wątpienia można mówić więc o symbolicznym znaczeniu barw. Przykładowo wystawa o ekonomii posługiwała się kolorem złotym, o zbrodni - czerwonym, o gender - różowym, o naturze - zielonym. Barwy przewodnie poszczególnych projektów pojawiają się na wszelkich materiałach promocyjnych, zwłaszcza plakatach i ulotkach, a także w katalogach wystawy. Nie występują natomiast w samej przestrzeni ekspozycji, aby nie ingerować $\mathrm{w}$ artystyczną wizję kuratora i artystów.

Jako największy atut wizerunkowy muzeum wskazuje właśnie unikalny architektonicznie budynek, twierdząc, że wielu odbiorców odwiedza muzeum właśnie ze względu na artystyczne walory jego siedziby. Pozytywny wizerunek instytucja chce budować poprzez zachowanie wizualnej - w tym kolorystycznej - spójności. Kiedy w obrębie muzeum powstawała biblioteka, w konkursie na jej projekt uwzględniono obowiązek zachowania przewodniego kodu kolorystycznego i kryterium to brano pod uwage podczas wyboru zwycięzcy. „Ludzie mają pewne znaki zakodowane jako symbole, ikony. I zachowanie takiej spójności, systematycznie, przez wiele lat, daje efekty" - mówiła Ewelina Czechowicz, kierownik Działu Promocji. 
Opera w Krakowie jednoznacznie legitymuje się kolorem czerwonym, który buduje jej wizerunek nawet wśród postronnych obserwatorów, konsekwentnie pojawiając się w większości elementów identyfikacji wizualnej: w budynku (zarówno wewnątrz, jak i na zewnątrz), logotypie, na stronie internetowej i w materiałach promocyjnych. „Okres czerwony” krakowskiej Opery rozpoczął się w roku 2004 wraz z budową własnej siedziby (projektu Romualda Loeglera), do czego prowadziła długa i niełatwa droga (rozpoczęta już w roku 1954) ${ }^{46}$.

Kompleks Opery składa się z trzech połączonych ze sobą części (il. 7). Jedna $z$ nich to zmodernizowana siedziba Operetki, dawniej służąca za ujeżdżalnię koni. Budynek nakryty został półokrągłym dachem i obity zielonym marmurem. Płynnie przechodzi on w część centralną - wysoką, silnie przeszkloną konstrukcję o intensywnie czerwonym kolorze, w której mieści się główna sala widowiskowa. Styka się z nią jednym z boków bryła części administracyjnej, w której przeszklenia przeplatane są emaliowanymi pasami w odcieniach błękitu i zieleni. W architekturze Opery występuje więc duża różnorodność kształtów, form, materiałów, a także barw. Widać też chęć połączenia współczesności z historią i tradycją.

Mimo wizualnej spójności, estetyka gmachu wzbudziła kontrowersje w potocznym odbiorze mieszkańców Krakowa. Głównym z zarzutów była właśnie jego kolorystyka, której zarzucano „pstrokatość”, „jarmarczność” i budzenie skojarzeń z galerią handlową ${ }^{47}$. Było to spowodowane w znacznej mierze tym, że wnętrze Opery także jest niemal całkowicie czerwone (il. 8). Kolor ten „zatapia” w sobie odbiorcę, otaczając go ze wszystkich stron. Tak o czerwieni Opery pisała Marta Leśniakowska:

46 Zob. J. Opalski, 50-lecie Opery Krakowskiej. Z dziejów teatru 1954-2004, red. J. Opalski, Kraków 2004, s. 90-124.

47 Tropiciele Makabryt: Upiorna Opera, https://www.bryla.pl/bryla/1,85300, 5576000,Tropiciele_Makabryl__Upiorna_Opera.html [dostęp 16.04.2020]. 


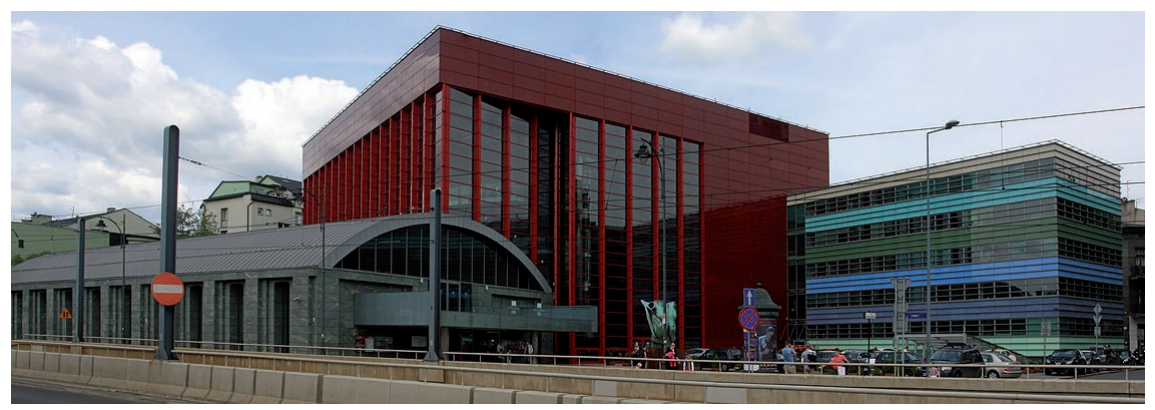

Il. 7

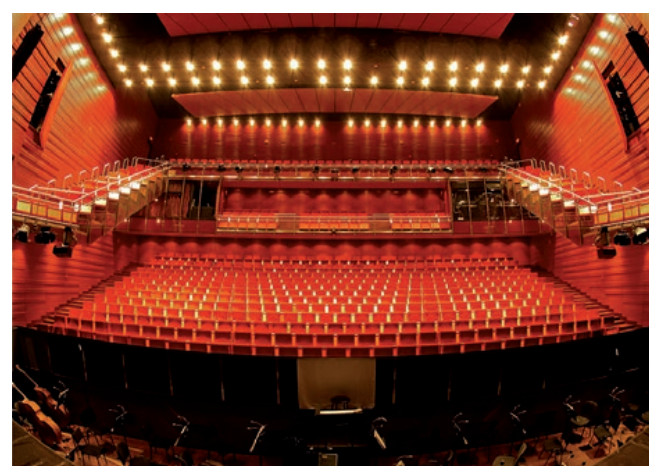

Il. 8

Przeszkloną elewację pokrywają bordowe płaszczyzny, a wnętrze wypełniają płynne „fałdy” ścian w kolorze wiśniowym, tafle wiśniowego szkła ścianek działowych, wiśniowe posadzki, parkiety i schody, ściany i drzwi z czerwonego szkła w toaletach; w sali widowiskowej fotele z buczyny barwionej na czerwono pokrywa wiśniowa tapicerka, szklane panele podwieszone u sufitu wykonane są z wiśniowego szkła, a świecące w podłodze numerki rzędów mają kolor rozgrzanego w piecu hutniczym stopu ${ }^{48}$.

Zdaniem autorki, kolor ten jest nawiązaniem do czerwieni występującej w dawnej, tradycyjnej architekturze operowej, ale nie jako rodzaj hołdu złożonego tradycji, ale prześmiewczego pastiszu. Sam architekt wskazuje jednak na czysto praktyczne zastosowanie tej barwy. W jednym z wywiadów mówił:

${ }_{48}$ M. Leśniakowska, Opera Krakowska, http://www.theatre-architecture.eu/pl/ db.html?theatreId=112 [dostęp 16.04.2020]. 
Ten kolor jest podyktowany moimi studiami nad tym, czego tak naprawdę od klimatu wnętrza oczekują muzycy. W większości teatrów muzycznych wnętrza sal są czerwone, bo czerwień pozytywnie oddziałuje na stan emocjonalny muzyków, lepiej im się gra ${ }^{49}$.

Znaczenie symboliczne ma natomiast kolorystyka dawnej ujeżdżalni (okrytej płytami z zielonkawego marmuru). Jak wyjaśniał Loegler:

Kolor tego kamienia jest symbolem nadziei na to, że ten budynek będzie zwiastował nowy etap w rozwoju historii tego teatru, a przede wszystkim, że spełni moje dwa największe oczekiwania, jakimi są: wysoki poziom artystyczny i kultura użytkowania tego budynku ${ }^{50}$.

Część administracyjna utrzymana jest w dwóch kolorach (zielonym i niebieskim), zastosowanych w kilku odcieniach. Także one nie są przypadkowe. Architekt tłumaczył:

Mieszanka kolorów na elewacji tego budynku ma symbolizować, że spełnia on funkcję użytkową dla dwóch pozostałych [jego części - przyp. A.B-H.]. [...] Projektując ten budynek, myślałem także o mieszkańcach przy ul. Topolowej. Chciałem, aby elewacja tego budynku, która będzie tłem ich codziennego życia, robiła bardziej pozytywne wrażenie niż szare kamienice ${ }^{51}$.

Chłodne kolory części wejściowej i administracyjnej są jednak słabo dostrzegalne w zestawieniu z przytłaczającą czerwienią głównej bryły. To ona nadaje ton całemu projektowi. Wszystko wskazuje na to, że to ona również wyznaczyła kierunek w systemie identyfikacji wizualnej Opery Krakowskiej. Logotyp Opery (il. 9) nawiązuje tematycznie do budynku, ale też powiela jego kolor. Składa się z czerwonego kwadratu, którego dolna krawędź jest delikatnie wklęsła, umieszczonego niżej napisu: Opera Krakowska oraz trzech ciemnoszarych, horyzontalnie ułożonych, lekko zaokrąglonych

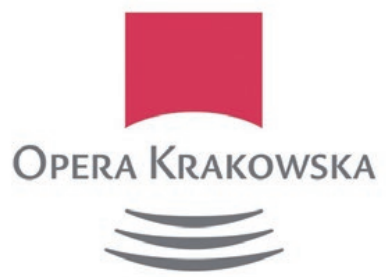

Il. 9

${ }^{49}$ A. Malatyńska-Stankiewicz, Z betonu i szkła, http://www.e-teatr.pl/pl/artykuly/63831,druk.html, [dostęp 16.04.2020].

50 Ibidem.

${ }^{51}$ Ibidem. 
linii. Logotyp przywodzi na myśl salę koncertową: czerwony kształt to scena, linie - rzędy widowni. Czerwień pojawia się również na stronie internetowej, będąc przeciwwagą dla bazowych szarości.

\section{PODSUMOWANIE}

Celem artykułu było ukazanie sposobów, w jaki instytucje mogą wykorzystywać barwy do kształtowania własnego wizerunku oraz wskazanie funkcji, jakie owe barwy pełnią.

Do sposobów wykorzystania barw zaliczyć można: użycie ich w systemie identyfikacji wizualnej (przede wszystkim logo oraz bazujące na nim materiały promocyjne: ulotki, gadżety, wizy tówki, plakaty) oraz zastosowanie ich w przestrzeni budynku. Przykład omówionych instytucji kultury pokazuje, że pierwszy element może być wtórny wobec drugiego. Gdy barwa budynku jest silną dominantą wzrokową, determinuje kolorystyczny wizerunek całej organizacji. Dla zarządzających wizerunkiem racjonalną postawą wydaje się wówczas dopasowanie pozostałych elementów identyfikacyjnych do koloru budynku, a nie tworzenie odrębnych jakości.

Barwy składające się na system identyfikacji wizualnej omówionych instytucji kultury pełnią różnorodne funkcje. Funkcjami praktycznymi są:

- zagwarantowanie efektu estetycznego (każda z opisanych instytucji ma na uwadze ten walor, przykładem jest zmiana kolorystyki gadżetów Filharmonii ze złoto-czarnych na biało-czarne, które lepiej prezentowały się wizualnie);

- $\quad$ wyróżnienie się z otoczenia (budynki Opery, które mają przykuwać uwagę krakowian oraz być atrakcyjnym krajobrazem dla mieszkańców okolicy);

- podkreślenie zróżnicowania oferty (muzeum MOCAK posługujące się odmiennymi kolorami dla różnych obszarów działalności oraz typów biletów);

- oddziaływanie psychofizyczne (czerwień w Operze pobudzająca grających muzyków).

Na funkcje symboliczne składają się:

- $\quad$ odwołanie do uniwersalnej symboliki kulturowej barw (złoto w logotypie Filharmonii oznaczające bogactwo, zielony marmur Opery symbolizujący nadzieję, przewodnie barwy tematycznych wystaw w MOCAK-u); 
- nawiązanie do typu instytucji i specyfiki jej działalności (Filharmonia legitymizująca się złotem jako instytucja prestiżowa, czerwień Opery odwołująca się do tradycji teatru);

- nawiązanie do wyglądu budynku, w którym organizacja funkcjonuje (wszystkie instytucje).

Poczyniona w artykule refleksja ukazała, że barwy mogą być przydatne do kształtowania wizerunku instytucji kultury. Sposoby ich użycia (logo, materiały promocyjne, wystrój budynku itp.) stwarzają szerokie możliwości w promocji i komunikacji z odbiorcami. Sądzę, że wykorzystanie kolorów w tego typu działaniach jest dobrą praktyką, z której placówki kulturalne mogą z powodzeniem korzystać. Warto, by zarysowany w tekście proces, który nazwać można „zarządzeniem kolorem”52, zyskiwał na popularności wśród funkcjonujących w Polsce organizacji, również tych związanych $\mathrm{z}$ branżą kulturalną.

\section{Bibliografia}

Jerzy Altkorn, Wizualizacja firmy, Instytut Marketingu, Kraków 1999.

Anna Benicewicz-Miazga, Grafika w biznesie. Logotypy, wizytówki, papier firmowy: projektowanie elementów tożsamości wizualnej, Helion, Gliwice 2005.

Zbigniew Bentyn, Identyfikacja wizualna przedsiębiorstwa, Wydawnictwo Naukowe PWSB, Poznań 2011.

Igor Borkowski, Karina Stasiuk-Krajewska, Wizerunek, opis świata, konstrukcja komunikacji, [w:] Kształtowanie wizerunku jako narzadzie public relations, red.

I. Borkowski, K. Stasiuk-Krajewska, Wydawnictwo UWr, Wrocław 2011.

Tomasz Dąbrowski, Reputacja przedsiębiorstwa: tworzenie kapitału zaufania, Wolters Kluwer Polska, Kraków 2010.

Gavin Evans, Historia kolorów. Tajemniczy świat barw, tłum. W. Jeżewski, Bellona, Warszawa 2019.

Eleonora Grimm, Kolor w środkach masowego przekazu, tłum. b.d., Ośrodek Badań Prasoznawczych RSW „Prasa”, Kraków 1971.

Rudolf Gross, Dlaczego czerwień jest barwą miłości, tłum. A. Porębska, WAiF, Warszawa 1990.

David Hornung, Kolor. Kurs dla artystów i projektantów, tłum. M. Brand, Universitas, Kraków 2009.

Kurt Huber, Image, czyli jak być gwiazdą na rynku, tłum. J. Sukiennicki, Business Press, Warszawa 1994.

52 Ibidem. 
Ewa Musiałowska, Budowanie wizerunku przez symbole, [w:] Kształtowanie wizerunku, red. B. Ociepka, Wydawnictwo Uniwersytetu Wrocławskiego, Wrocław 2005.

Agata Niemczyk, Marketing w sferze kultury, Wydawnictwo Akademii Ekonomicznej w Krakowie, Kraków 2007.

Stanisław Popek, Barwy i psychika. Percepcja, ekspresja, projekcja, Wydawnictwo UMCS, Lublin 2012.

Dominika Popiel, Ochrona prawna marki, [w:] Instrumenty ksztattowania wizerunku marki, red. A. Grzegorczyk, Wyższa Szkoła Promocji w Warszawie, Warszawa 2005.

Bernd Schmitt, Alex Simonson, Estetyka $w$ marketingu, tłum. M. Bernacki, Wydawnictwo Profesjonalnej Szkoły Biznesu, Kraków 1999.

Małgorzata Snarska, Corporade design - wizualizacja tożsamości, [w:] Kształtowanie wizerunku, red. B. Ociepka, Wydawnictwo UWr Wrocław 2005.

Ewa Stopa-Pielesz, Corporate design: czyli jak sprawić, by estetyka pracowała na sukces firmy, Wydawnictwo Profesjonalnej Szkoły Biznesu, Kraków 2002.

Józef Szocki, Wizerunek firmy w mediach, Wydawnictwo Forum Naukowe, PoznańWrocław 2008.

Ryszard Tokarski, Semantyka barw we współczesnej polszczyźnie, Wydawnictwo UMCS, Lublin 2004.

Gisela Watermann, Kolor w mieszkaniu: barwy, kształty, oświetlenie, materiały, tłum. A. Konopacka, Kalliope, Warszawa 1994.

Krystyna Wojcik, Public relations. Wiarygodny dialog z otoczeniem, Placet, Warszawa 2009.

Jarosław Woźniczka, Uniwersalność koncepcji marketingowej a specyfika rynku kultury i sztuki, [w:] Kultura w gospodarce rynkowej. Problemy adaptacji marketingu, red. K. Mazurek-Łopacińska, Wydawnictwo Akademii Ekonomicznej we Wrocławiu, Warszawa-Wrocław 1997.

Gerhard Zeugner, Barwa i człowiek, tłum. J. Rogaczewski, Arkady, Warszawa 1965.

Jolanta Zrałek, Znaczenie wizerunku przedsiębiorstwa w wyborach konsumentów ( $w$ świetle racjonalności), Wydawnictwo Akademii Ekonomicznej w Katowicach, Katowice 2005.

Agnieszka Żbikowska, Public relations, Polskie Wydawnictwo Ekonomiczne, Warszawa 2005.

50-lecie Opery Krakowskiej. Z dziejów teatru 1954-2004, red. J. Opalski, Opera Krakowska, Kraków 2004.

\section{Źródła internetowe}

M. Leśniakowska, Opera Krakowska, http://www.theatre-architecture.eu/pl/db.html?theatreId=112 [dostęp 16.04.2020].

A. Malatyńska-Stankiewicz, $Z$ betonu $i$ szkła, http://www.e-teatr.pl/pl/artykuly/63831,druk.html, [dostęp 16.04.2020]. 
Muzeum Sztuki Współczesnej w Krakowie MOCAK - Historia, https://www.mocak. $\mathrm{pl} /$ historia [dostęp 16.04.2020]

Oddziały - Muzeum Krakowa, https://www.muzeumkrakowa.pl/oddzialy [dostęp 16.04.2020].

Oddziały - Muzeum Narodowe w Krakowie, https://mnk.pl/oddzialy [dostęp 16.04.2020].

Tropiciele Makabryt: Upiorna Opera, https://www.bryla.pl/bryla/1,85300,5576000,Tropiciele_Makabryl__Upiorna_Opera.html [dostęp 16.04.2020].

Wojewódzka Biblioteka Publiczna w Krakowie, https://www.rajska.info/ [dostęp 16.04.2020].

\section{Źródła ilustracji}

Il. 1. Budynek Filharmonii im. Karola Szymanowskiego w Krakowie, https://lovekrakow.pl/aktualnosci/pozar-poddasza-w-filharmonii-krakowskiej_34121.html [dostęp 8.04.2021].

Il. 2. Wnętrze sali koncertowej w Filharmonii Krakowskiej (fot. Klaudyna Schubert). Dzięki uprzejmości Filharmonii Krakowskiej.

Il. 3. Logotyp Filharmonii im. Karola Szymanowskiego w Krakowie. Dzięki uprzejmości Filharmonii Krakowskiej.

Il. 4. Budynek Muzeum Sztuki Współczesnej w Krakowie MOCAK, https://www. mocak.pl/kontakt [dostęp 8.04.2021].

Il. 5. Wnętrze Muzeum Sztuki Współczesnej w Krakowie MOCAK, https://aasarchitecture.com/2013/04/mocak-by-claudio-nardi-architects.html/mocak-by-claudio-nardi-architects-08/ [dostęp 8.04.2021].

Il. 6. Logotyp Muzeum Sztuki Współczesnej w Krakowie MOCAK, https://www.mocak. pl/logo-mocak-u [dostęp 8.04.2021].

Il. 7. Budynek Opery Krakowskiej, http://krakow.fotopolska.eu/554801,foto.html [dostęp 8.04.2021].

Il. 8. Wnętrze sali koncertowej w Operze Krakowskiej, https://ltt.com.pl/realizacja/ opera-krakowska [dostęp 8.04.2021].

Il. 9. Logotyp Opery Krakowskiej, https://opera.krakow.pl/pakiety-logotypow [dostęp 8.04.2021].

\section{The Use of Colors in Shaping the Image of Cultural Institutions}

Colors are the basic element of the visual identity system, which is important in shaping the image of an organization among target groups. Deliberate use of colors can help consolidate its positive image among the recipients, which will translate into achieving its strategic goals. The article attempts to answer the question of how institutions can use colors to shape their image. In the first part of the work, the 
issue of image is discussed. The second section presents the general characteristics of colors, their psychophysical and symbolic properties, and then the possibilities to use colors in the visual identification system (logotype, promotional prints, website, building space). In the third part, theoretical principles are confronted with practice. The ways of using colors in shaping the image of three cultural institutions in Kraków (Opera, Philharmonic, MOCAK Museum of Contemporary Art in Krakow) are described, based on ethnographic research (participant observation, interviews with employees). Data analysis allowed to distinguish ways of using colors and functions they perform (practical and symbolic).

Keywords: Colors, visual identity system, image, cultural institutions in Kraków

Data otrzymania tekstu: 3.05.2020 r.

Data zakończenia procesu recenzyjnego: 20.03.2021 r.

Data akceptacji tekstu do druku: 29.03.2021 r. 